\title{
Growing and finishing crossbred feedlot ewe lambs fed with increasing levels of concentrate in the diet
}

\section{Recria e terminação de cordeiras mestiças em confinamento alimentadas com níveis crescentes de concentrado na dieta}

\author{
Caroline Bertholini Ribeiro'; Maria da Graça Morais ${ }^{2}$; Andréa Roberto Duarte \\ Lopes Souza $^{3 *}$; Henrique Jorge Fernandes ${ }^{4}$; Camila Celeste Brandão Ferreira \\ Ítavo²; Gumercindo Loriano Franco²; Mayara Mitiko Yoshihara Carneiro'; Raizza \\ Fátima Abadia Tulux Rocha ${ }^{5}$; Bruna Biava de Menezes ${ }^{1}$; Catherine Cecília Walker ${ }^{1}$
}

\begin{abstract}
To maximize economic gain in sheep production systems it is critical to adjust feedlot diets to maximize performance while minimizing feed, and especially concentrate, waste. Little information is available on ideal diets for crossbred ewe lambs. Therefore, this study aimed to evaluate the performance of feedlot crossbred ewe lambs, and the digestibility of diets, with increasing levels of concentrate during the growing and finishing phases. Twenty-four crossbred Texel $\times$ Pantaneira Texel ewe lambs were confined and fed Tifton hay with increasing levels of concentrate in the diet $(20,40,60$ and 80\%) for individual evaluation of dry matter intake (DMI), digestibility of diets, average daily gain (ADG) and feed efficiency (FE). Animals were slaughtered at $47 \mathrm{~kg}$. In the growing phase, the inclusion of concentrate in the diets $\left(1176{\mathrm{~g} . \mathrm{kg}^{-1}}^{-1}\right)$ did not change DMI $(\mathrm{p}>0.05)$. Concentrate levels had a quadratic effect $(p<0.05)$ on the dry matter digestibility coefficient (DMDC) and on total digestible nutrients (TDN) during the growing phase. In the finishing phase, there was a negative linear effect of concentrate levels on DMI $(\mathrm{p}<0.05)$, but TDN intake was similar among the experimental diets $(\mathrm{p}>0.05)$. DMDC and TDN values displayed a quadratic behavior $(p<0.05)$, plateauing at $60 \%$ concentrate. ADG and FE increased as concentrate was added to the diet in the growing phase $(\mathrm{p}<0.05)$. During the finishing phase, lamb performance was similar $(p>0.05)$ for different diets. Thus, the use of $60 \%$ concentrate in the confined crossbred ewe lamb diet during growing and $20 \%$ concentrate during finishing is recommended.
\end{abstract}

Key words: Feedlot. Digestibility coefficient. Intake. Weight gainh.

\section{Resumo}

Para maximizar o ganho econômico em sistemas de produção de ovinos é fundamental ajustar as dietas de confinamento para aumentar o desempenho e minimizar os custos e desperdícios com

\footnotetext{
${ }^{1}$ Discentes do Curso de Doutorado do Programa de Pós-Graduação em Ciência Animal, Faculdade de Medicina Veterinária e Zootecnia, Universidade Federal de Mato Grosso do Sul, UFMS, Campo Grande, MS, Brasil. E-mail: cbr_calu@yahoo.com.br; mayara_mitiko@hotmail.com; bruna_biava@hotmail.com; catherinecwalker@hotmail.com

2 Profs., Departamento de Zootecnia, Faculdade de Medicina Veterinária e Zootecnia, UFMS, Campo Grande, MS, Brasil. E-mail: morais.mariazinha@gmail.com; camila.itavo@ufms.br; gumercindo.franco@ufms.br

${ }^{3}$ Pesquisadora do Programa de Desenvolvimento Científico Regional, DCR/CNPq/FUNDECT, Departamento de Zootecnia da Faculdade de Medicina Veterinária e Zootecnia, UFMS, Campo Grande, MS, Brasil. E-mail: andreardl_dagher@yahoo.com.br

${ }^{4}$ Prof., Departamento de Zootecnia, UFMS, Aquidauana, MS. E-mail: henrique.uems@hotmail.com

${ }_{5}$ Discente do Curso de Mestrado do Programa de Pós-Graduação em Ciência Animal, Faculdade de Medicina Veterinária e Zootecnia, UFMS, Campo Grande, MS, Brasil. E-mail: raizza_ra@hotmail.com

* Author for correspondence
} 
alimentação, especialmente com concentrado. Existem poucas informações sobre avaliação de dietas ideais para cordeiras mestiças. Objetivou-se avaliar o desempenho de cordeiras mestiças confinadas e a digestibilidade de dietas com níveis crescentes de concentrado durante as fases de recria e terminação. Foram confinadas 24 fêmeas mestiças Texel (1/2 Pantaneira x 1/2 Texel) alimentadas com feno de capim-Tifton e níveis crescentes de concentrado na dieta (20, 40, 60 e 80\%) para avaliação individual do consumo de matéria seca (CMS), digestibilidade dos nutrientes das dietas, ganho médio diário (GMD) e eficiência alimentar (EA). Os animais foram abatidos com $47 \mathrm{~kg}$. Na fase de recria, o CMS não foi alterado $(\mathrm{p}>0,05)$ pela inclusão de concentrado nas dietas $\left(1176 \mathrm{~g} \mathrm{~kg}^{-1}\right)$. Foi observado efeito quadrático dos níveis de concentrado $(\mathrm{p}<0,05)$ sobre os coeficientes de digestibilidade de matéria seca (CDMS) e nutrientes digestíveis totais (NDT) durante a recria. Na fase de terminação, houve efeito linear negativo dos níveis de concentrado sobre o CMS $(\mathrm{p}<0,05)$, porém a ingestão de NDT foi similar entre as dietas experimentais $(\mathrm{p}>0,05)$. O CDMS e o valor de NDT apresentaram comportamento quadrático $(\mathrm{p}<$ 0,05 ), com o platô obtido com a inclusão de $60 \%$ de concentrado. O GMD e a EA aumentaram com a inclusão de concentrado nas dietas na recria $(\mathrm{p}<0,05)$. Durante a fase de terminação, as cordeiras apresentaram desempenho semelhante $(\mathrm{p}>0,05)$ para as diferentes dietas experimentais. Recomenda-se a inclusão de $60 \%$ de concentrado na dieta de cordeiras mestiças confinadas durante a recria e $20 \%$ de concentrado na terminação.

Palavras-chave: Confinamento. Consumo. Coeficiente de digestibilidade. Ganho de peso.

\section{Introduction}

Nutritional management in feedlot, with diets with a high proportion of concentrate and high content of total digestible nutrients, is critical to allow sheep to express their maximum genetic potential for nutrient use and performance (FRESCURA et al., 2005). In the growing phase, feedlot confinement usually aims to ensure reproductive precocity of females and to decrease the slaughter age of males. However, in the finishing phase, confinement of lambs and cull ewes focuses on supplying diets with high energy density to promote performance, resulting in carcasses that attain the fat cover requirements of the meat packing industry (CARASSAI et al., 2008; CUNHA et al., 2008).

In general, the more digestible diets provided in feedlot promote dry matter intake, but there is a physiological limit to the digestion and absorption of nutrients, related to the energy and protein requirements of the animal. The recommended amounts of concentrate and other ingredients for male lamb diets are well established in the literature (KOZLOSKI et al., 2006; MORENO et al., 2010; CARVALHO et al., 2015). However, those have reduced applicability in diets for crossbred females, as there are differences between the sexes in the growth and development rates of tissues in the growing and finishing phases (OWENS et al., 1993), resulting in different diet utilization efficiencies, even when considering individuals with the same weight, due to the differences in body composition.

Ascertaining the nutrient utilization capacity in ewe lambs is essential to determine the limits of diet utilization and to avoid supplying excessive concentrate, with potential harmful effects, such as acidosis and decreased digestibility due to a higher grain throughput rate. Determining the appropriate level of concentrate in the animal diet can also prevent feed waste in the feedlot and improve performance during the growing and finishing phases (GERON et al., 2013). Thus, this study aimed to evaluate the performance of feedlot crossbred ewe lambs and the digestibility of diets with increasing levels of concentrate during the growing and finishing phases.

\section{Materials and Methods}

The experiment was conducted at the Animal Metabolism Laboratory at the Universidade Federal Mato Grosso do Sul (UFMS) Faculty of Veterinary Medicine and Animal Science, in Campo Grande, MS, Brazil, between the months of August and December, totaling 128 days of confinement. 
Twenty-four crossbred (Pantaneira $\times$ Texel) wool ewe lambs were used, weighing $24.6 \pm 3.3 \mathrm{~kg}$ and with $4 \pm 1$ months average initial age. The experiment was conducted after approval by the UFMS Ethics Committee on Animal Use (filing \# 235/2009) and the care and use of ewe lambs were performed according to the standards for the use of animals in exp eriments.

The animals were distributed in individual stalls and four levels of concentrate in the diet were evaluated (20,40, 60 and 80\%) during the growing (September to October) and finishing (October to December) phases. The roughage used was Tifton 85 (Cynodon spp.) hay, milled through a $1 \mathrm{~cm}$ sieve. The concentrate composition was ground corn, soybean meal, dry brewer's yeast, powdered sugar cane molasses, vitamin-mineral premix, dicalcium phosphate, calcium carbonate, sodium bicarbonate and urea. The diets were formulated according to NRC (2007) to yield a weight gain of 100, 150, 200 and 250 g.animal ${ }^{-1}$.day ${ }^{-1}$ for the 20, 40, 60 and $80 \%$ concentrate levels, respectively (Table 1 ).

At the beginning of the experiment, the animals were weighed, treated against ecto- and endoparasites (Closantel ${ }^{\circledR}$, Cidectin ${ }^{\circledR}$ and Baycox $\left.{ }^{\circledR}\right)$ and distributed in $3 \mathrm{~m}^{2}$ individual stalls, with trough and drinking fountain. During the 28 days of adaptation, each animal was provided with hay and gradually increasing dosage of concentrate, up to the level set for each diet. Urea was added to the 20, 40 and $60 \%$ concentrate diets (at 2.36, 1.57 and 0.79 g.animal ${ }^{-1}$.day ${ }^{-1}$, respectively). The animals were fed twice a day, at 8 am and $2 \mathrm{pm}(60 \%$ of total feed in the morning and $40 \%$ in the afternoon). The feed supplied to each animal was adjusted daily based the food refusals, which were kept at $10 \%$ of the offered, to assure voluntary consumption. Mineral supplement and water were provided ad libitum to the animals.

During the experiment, five feces collections were performed to determine the nutrient digestibility coefficient. Three collections were during the growing phase and two during the finishing phase, with 13 day intervals between collections of each phase. Stool samples were obtained over 48 hours with collecting bags, to determine the total fecal output and to obtain a representative amount of feces to be sampled. When the weight of the stool of an animal exceeded $100 \mathrm{~g}$, the material was homogenized and a $50 \mathrm{~g}$ sample was used; if the stool collected weighed less than $50 \mathrm{~g}$, the sample was made up of all the collected material. Samples of hay, concentrate and food leftovers from each trough were also collected in the feces collection days. All this material was identified, and then stored at $-20^{\circ} \mathrm{C}$ in a freezer for further analysis.

The chemical analysis of the samples was carried out at the Universidade Federal do Mato Grosso do Sul Laboratory of Animal Nutrition. After predrying, each sample was ground in a knife mill, with a $1 \mathrm{~mm}$ sieve, and analyzed for dry matter (DM), mineral content (MC), crude protein $(\mathrm{CP})$, ether extract (EE), neutral detergent fiber (NDF), acid detergent fiber (ADF), insoluble nitrogen in neutral detergent (INND) and insoluble nitrogen in acid detergent (INAD) as described by Silva and Queiroz (2002). For determination of Tifton grass hay nonfiber carbohydrate content (NFC), the equation used was: $\mathrm{NFC}=\mathrm{OM}-\left(\mathrm{CP}+\mathrm{EE}+\mathrm{NDF}-\mathrm{CP}_{\text {urea }}+\right.$ urea $)$ (HALL, 2000). Total digestible nutrients (TDN) were estimated according to NRC (2007): TDN = $\left(\mathrm{CP}_{\text {diet }}-\mathrm{CP}_{\text {feces }}\right)+\left(\mathrm{NDF}_{\text {diet }}-\mathrm{NDF}_{\text {feces }}\right)+\left(\mathrm{NFC}_{\text {diet }}-\right.$ $\left.\mathrm{NFC}_{\text {feces }}\right)+\left(2.25 \times\left(\mathrm{EE}_{\text {diet }}-\mathrm{EE}_{\text {feces }}\right)\right)$.

The animals were weighed at the beginning and at the end of growing (40 days of confinement) to obtain the initial body weight at fast in the growing phase. The initial weight of the finishing phase (60 days confinement) was equivalent to the final body weight of the growing phase. Average daily gain (ADG) was calculated, in the growing and finishing phases, as the ratio between the total weight gain and the number of days of confinement in each phase. Feed efficiency (FE) was calculated by the ratio of ADG $\left(\mathrm{kg}^{\mathrm{day}}{ }^{-1}\right)$ and dry matter intake $(\mathrm{kg}$. day $\left.^{-1}\right)$. 
Table 1. Chemical composition of the experimental diets and ingredients, based on dry matter.

\begin{tabular}{|c|c|c|c|c|}
\hline \multicolumn{5}{|c|}{ Ingredients $\left(\mathrm{g} \mathrm{kg}^{-1} \mathrm{DM}\right)^{1}$} \\
\hline Components & Tifton 85 hay & Concentrate $^{2}$ & Urea & Mineral supplement $^{3}$ \\
\hline $\mathrm{DM}\left(\mathrm{g} \mathrm{kg}^{-1}\right)$ & 923.9 & 903.8 & 980.0 & 987.0 \\
\hline $\mathrm{OM}\left(\mathrm{g} \mathrm{kg}^{-1} \mathrm{DM}\right)$ & 937.7 & 940.5 & - & - \\
\hline $\mathrm{CP}\left(\mathrm{g} \mathrm{kg}^{-1} \mathrm{DM}\right)$ & 106.5 & 278.8 & 2.820 & - \\
\hline $\mathrm{EE}\left(\mathrm{g} \mathrm{kg}^{-1} \mathrm{DM}\right)$ & 23.3 & 28.7 & - & - \\
\hline NDFp $\left(\mathrm{g} \mathrm{kg}^{-1} \mathrm{DM}\right)$ & 769.7 & 304.2 & - & - \\
\hline $\operatorname{Lignin}\left(\mathrm{g} \mathrm{kg}^{-1} \mathrm{DM}\right)$ & 52.0 & 4.6 & - & - \\
\hline $\mathrm{NFC}^{4}\left(\mathrm{~g} \mathrm{~kg}^{-1} \mathrm{DM}\right)$ & 36.9 & 355.4 & - & - \\
\hline $\mathrm{Ca}\left(\mathrm{g} \mathrm{kg}^{-1} \mathrm{DM}\right)$ & 3.26 & 8.70 & - & 146.49 \\
\hline $\mathrm{P}\left(\mathrm{g} \mathrm{kg}^{-1} \mathrm{DM}\right)$ & 2.04 & 4.65 & - & 94.47 \\
\hline $\mathrm{Mg}\left(\mathrm{g} \mathrm{kg}^{-1} \mathrm{DM}\right)$ & 2.03 & 1.99 & - & 12.10 \\
\hline \multirow{2}{*}{ Components } & \multicolumn{4}{|c|}{ Forage:concentrate ratio } \\
\hline & $80: 20$ & $60: 40$ & $40: 60$ & $20: 80$ \\
\hline $\mathrm{DM}\left(\mathrm{g} \mathrm{kg}^{-1}\right)$ & 919.8 & 915.8 & 911.8 & 907.8 \\
\hline $\mathrm{OM}\left(\mathrm{g} \mathrm{kg}^{-1} \mathrm{DM}\right)$ & 938.3 & 938.8 & 939.4 & 939.9 \\
\hline $\mathrm{CP}\left(\mathrm{g} \mathrm{kg}^{-1} \mathrm{DM}\right)$ & 202.3 & 209.2 & 216.1 & 223.1 \\
\hline $\mathrm{EE}\left(\mathrm{g} \mathrm{kg}^{-1} \mathrm{DM}\right)$ & 24.4 & 25.4 & 26.5 & 27.6 \\
\hline NDFp (g kg-1 DM) & 676.6 & 583.5 & 490.4 & 397.3 \\
\hline $\operatorname{Lignin}\left(\mathrm{g} \mathrm{kg}^{-1} \mathrm{DM}\right)$ & 42.5 & 33.0 & 23.6 & 14.1 \\
\hline $\mathrm{NFC}\left(\mathrm{g} \mathrm{kg}^{-1} \mathrm{DM}\right)$ & 100.6 & 164.3 & 228.0 & 291.7 \\
\hline $\mathrm{Fe}\left(\mathrm{mg} \mathrm{kg}^{-1} \mathrm{DM}\right)$ & 191.2 & 158.8 & - & 3.847 \\
\hline $\mathrm{Mn}\left(\mathrm{mg} \mathrm{kg}^{-1} \mathrm{DM}\right)$ & 81.0 & 51.1 & - & 969.0 \\
\hline $\mathrm{Zn}\left(\mathrm{mg} \mathrm{kg}{ }^{-1} \mathrm{DM}\right)$ & 33.5 & 80.0 & - & 1.599 \\
\hline $\mathrm{Cu}\left(\mathrm{mg} \mathrm{kg}^{-1} \mathrm{DM}\right)$ & 5.15 & 12.7 & - & 209.9 \\
\hline
\end{tabular}

${ }^{1}$ Dry matter express in $\mathrm{g} . \mathrm{kg}^{-1}$ and other components in $\mathrm{g} \mathrm{kg}^{-1}$ of DM.

${ }^{2}$ Ingredients: was ground corn, soybean meal, dry brewer's yeast, powdered sugar cane molasses, vitamin-mineral premix, dicalcium phosphate, calcium carbonate, sodium bicarbonate and urea.

${ }^{3}$ Estimated by equation of Hall (2000): NFC $=100-[(\mathrm{CP}-\mathrm{CP}$ derived from urea + urea $)+\mathrm{NDFp}+\mathrm{EE}+$ ash $]$; NFC $=$ non-fiber carbohydrate; $\mathrm{CP}=$ crude protein; $\mathrm{NDFp}=$ neutral detergent fiber corrected for protein; $\mathrm{EE} \%=$ ether extract.

The experimental design was completely randomized with six replicates per treatment. Data were analyzed with a repeated-measures model, with each animal representing an experimental unit. The body weight of animals at the end of the experiment was included in the model as a covariate. The linear effects (CLE) and quadratic effects (CQE) of concentrate levels in the diet were evaluated by the decomposition of the sum of the squares for each treatment, through orthogonal contrasts (STEEL et al., 1997).

After identifying significant effects, the equations were adjusted for prediction of the response variables from the concentrate level. We used the PROC MIXED routine of the SAS v. 9.2 software (SAS INST. INC., 2009) to evaluate the effects and the PROC REG routine for adjustment of prediction equations. The significance level for statistical analyses was 5\%.

\section{Results and Discussion}

This study investigated the response of feedlot crossbred ewe lambs to increasing levels of concentrate in the diet regarding both performance and digestibility. The effects of these diets were evaluated in the growing and finishing phases. Increasing levels of concentrate had no effect ( $p$ $>0.05$ ) on dry matter intake (DMI) or organic matter intake (OMI) during the growing phase (Table 2). 
Increasing levels of concentrate had positive linear effects $(\mathrm{p}<0.05)$ on the consumption of crude protein $(\mathrm{CP})$, ether extract $(\mathrm{EE})$, non-fibrous carbohydrates (NFC) and total digestible nutrients (TDN), expressed in absolute values (g.animal ${ }^{-1}$. day $\left.^{-1}\right)$, but a negative effect $(\mathrm{p}<0.05)$ on the intake of neutral detergent fiber (NDF) and acid detergent fiber (ADF). The $80 \%$ concentrate treatment had
$16 \%$ more energy content available (TDN) than the $20 \%$ concentrate treatment. This was expected, as the proportion of each nutrient increased with the level of concentrate in the diet (Table 1). However, although energy availability increases with the proportion of concentrate in the diet, nutrient utilization is not always proportional to the level of concentrate.

Table 2. Least-squares mean, standard error, linear effect (LE) and quadratic effect (QE) of increasing levels of concentrate in the consumption of nutrients by crossbred lambs in the growing phase.

\begin{tabular}{|c|c|c|c|c|c|c|}
\hline \multirow{2}{*}{ Variables } & \multicolumn{4}{|c|}{ Concentrate levels } & \multicolumn{2}{|c|}{ P-Value } \\
\hline & $20 \%$ & $40 \%$ & $60 \%$ & $80 \%$ & CLE & $\mathrm{CQE}$ \\
\hline \multicolumn{7}{|c|}{ Nutrient consumption, g/Day } \\
\hline $\mathrm{DM}$ & $1196 \pm 28$ & $1139 \pm 23$ & $1177 \pm 23$ & $1193 \pm 28$ & 0.944 & 0.124 \\
\hline $\mathrm{OM}$ & $1124 \pm 27$ & $1069 \pm 21$ & $1108 \pm 22$ & $1127 \pm 26$ & 0.939 & 0.099 \\
\hline $\mathrm{CP}$ & $187 \pm 6$ & $215 \pm 5$ & $252 \pm 5$ & $273 \pm 6$ & $<0.0001$ & 0.472 \\
\hline $\mathrm{EE}$ & $29 \pm 0.8$ & $29 \pm 0.6$ & $33 \pm 0.7$ & $35 \pm 0.8$ & $<0.0001$ & 0.164 \\
\hline NFC & $148 \pm 8$ & $209 \pm 6$ & $290 \pm 6$ & $353 \pm 8$ & $<0.0001$ & 0.873 \\
\hline $\mathrm{NDF}$ & $778 \pm 15$ & $639 \pm 12$ & $553 \pm 12$ & $465 \pm 14$ & $<0.0001$ & 0.039 \\
\hline $\mathrm{ADF}$ & $399 \pm 7$ & $301 \pm 6$ & $233 \pm 6$ & $153 \pm 7$ & $<0.0001$ & 0.139 \\
\hline TDN & $782 \pm 18$ & $826 \pm 15$ & $904 \pm 15$ & $922 \pm 18$ & $<0.0001$ & 0.388 \\
\hline
\end{tabular}

DM: dry matter; OM: organic matter; CP: crude protein; EE: ether extract; NFC: non-fibrous carbohydrate; NDF: neutral detergent fiber; ADF: acid detergent fiber; TDN: total digestible nutrients.

This was reflected in the quadratic effect $(p<0.05)$ of dietary concentrate levels on the digestibility coefficients (DC) DMDC, OMDC, CPDC, EEDC, NFCDC, NDFDC, and ADFDC, and on TDN values observed for ewe lambs in the growing phase (Figure 1). The values of CPDC, EEDC, NFCDC and TDN observed are consistent with the behavior of DMDC and OMDC; however, the reductions in NDFDC and ADFDC are unrelated to them. Diet digestibility reached a plateau, indicating that the inclusion of $60 \%$ concentrate in the diet during the growing phase is enough to promote the efficient use of nutrients and maximize energy intake (Figure $1)$.

Above $60 \%$ concentrate, TDN values remain stable, suggesting that the animals reached a physiological limit for concentrate utilization, possibly due to limitations in pancreatic amylase production, limiting carbohydrate degradation and absorption capacity of the intestine of the ruminants (OWENS et al., 1986). This implies that providing concentrate above this proportion is unnecessary. Naturally, other components of the production system should be evaluated to establish the optimal inclusion level of concentrate for the growing phase based on performance, as other factors besides nutrient digestibility, such as the adult size and body composition, affect the efficiency of dietary energy use for maintenance and weight gain (NRC, 2007).

Concentrate levels had a quadratic effect (Figure 1) on the values of neutral detergent fiber (NDF) and acid detergent fiber (ADF) digestibility ( $p$ $<0.05$ ). This contrasts with the expected negative linear effect, since, according to Silva et al. (2015), adding concentrate to the diet of feedlot sheep can negatively affect $\mathrm{pH}$, and thus growth and 
performance of the fibrolytic bacteria responsible for ruminal degradation of dietary fiber, reducing NDF and ADF digestibility. Possibly the quadratic effects observed for NDFDC and ADFDC are associated with a reduced intake of these components (Table 2 ), and with an increase of protein concentration due to the inclusion of increasing levels of concentrate, as well as to the bicarbonate present. This may have helped maintain normal $\mathrm{pH}$, establishing favorable conditions for ruminal degradation and contributing to improve digestibility by approximately $40 \%$, even with twice the supply of NFC, compared to the diet with $20 \%$ and $60 \%$ concentrate (digestibility plateau).

Figure 1. Dry matter digestibility coefficient (DMDC), organic matter (OMDC), crude protein (CPDC), ether extract (EEDC), non-fibrous carbohydrate (NFCDC), neutral detergent fiber (NDFDC), acid detergent fiber (ADFDC) and total digestible nutrients (NDT) by crossbred lambs in the growing phase.

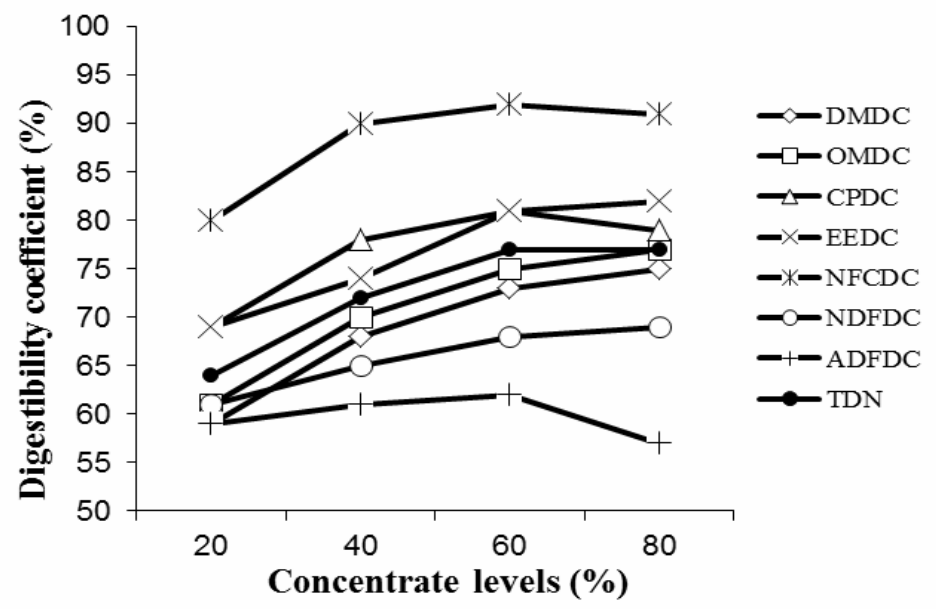

In the finishing phase, concentrate inclusion levels had a negative linear effect $(p<0.05)$ on the intake of DM, OM, EE, NDF and ADF, in g.animal ${ }^{-1}$. day $^{-1}$ (Table 3). The reduced consumptions of EE, NDF and ADF are related to the lower DMI and OMI, which in turn may have been affected by the proportional increase of NFC $(p<0.05)$ and by the lower content of other nutrients in the diet when greater proportions of concentrate were offered to the lambs. Bolzan et al. (2007) also observed the downward trend of the NDF intake as the concentrate level increased for feedlot lambs fed with diets with increasing levels of concentrate.

The NDF levels in the diets highest in concentrate (Table 1) indicated no lack of effective fiber (necessary for $\mathrm{pH}$ maintenance and microorganism survival) which could compromise the degradation of fibrous and non-fibrous components and reduce TDN intake. The $80 \%$ concentrate diet had $39.7 \%$
NDF, well above the minimum content of physically effective NDF for a proper functioning of the rumen, which must be at least 20\% (KOZLOSKI et al., 2006).

Increasing levels of concentrate did not affect TDN intake $(p>0.05)$, even with the reduction in DMI. This is likely related to the higher energy density of diets with high proportions of concentrate, and to the positive associative effect of the feed ingredients. The metabolizable energy demand of the animal to meet maintenance and weight gain requirements determines TDN intake (NRC, 2007). In this work, TDN intake supported the total requirements of animals regardless of the variation in body weight at finishing (33-50 kg). In the finishing phase, a quadratic effect of concentrate levels was observed on the DM, OM, CP and TDN digestibility coefficients (Figure 2). 
Table 3. Least-squares mean, standard error, linear effect (LE) and quadratic effect (QE) of increasing levels of concentrate in the consumption of nutrients by crossbred lambs in the finishing phase.

\begin{tabular}{ccccccc}
\hline \multirow{2}{*}{ Variables } & \multicolumn{3}{c}{ Concentrate levels } & \multicolumn{2}{c}{ P-Value } \\
\cline { 2 - 6 } & $20 \%$ & $40 \%$ & $60 \%$ & $80 \%$ & CLE & CQE \\
\hline \multicolumn{7}{c}{ Nutrient consumption, g/Day } \\
DM & $1450 \pm 41$ & $1328 \pm 31$ & $1295 \pm 31$ & $1207 \pm 41$ & 0.002 & 0.582 \\
OM & $1355 \pm 38$ & $1243 \pm 29$ & $1217 \pm 29$ & $1139 \pm 38$ & 0.003 & 0.555 \\
CP & $235 \pm 8$ & $257 \pm 6$ & $281 \pm 6$ & $278 \pm 8$ & 0.007 & 0.063 \\
EE & $38.1 \pm 1.1$ & $35.2 \pm 0.8$ & $34.1 \pm 0.8$ & $32.2 \pm 1.1$ & 0.005 & 0.519 \\
NFC & $180 \pm 9$ & $238 \pm 7$ & $295 \pm 7$ & $330 \pm 9$ & $<.0001$ & 0.086 \\
NDF & $931 \pm 23$ & $747 \pm 18$ & $623 \pm 18$ & $488 \pm 23$ & $<.0001$ & 0.173 \\
ADF & $455 \pm 11$ & $336 \pm 8$ & $235 \pm 8$ & $130 \pm 11$ & $<.0001$ & 0.367 \\
TDN & $1000 \pm 26$ & $973 \pm 20$ & $996 \pm 20$ & $923 \pm 26$ & 0.100 & 0.253 \\
\hline
\end{tabular}

DM: dry matter; OM: organic matter; CP: crude protein; EE: ether extract; NFC: non-fibrous carbohydrate; NDF: neutral detergent fiber; ADF: acid detergent fiber; TDN: total digestible nutrients.

Figure 2. Dry matter digestibility coefficient (DMDC), organic matter (OMDC), crude protein (CPDC), ether extract (EEDC), non-fibrous carbohydrate (NFCDC), neutral detergent fiber (NDFDC), acid detergent fiber (ADFDC) and total digestible nutrients (NDT) by crossbred lambs in the finishing phase.



The values of crude protein and TDN digestibility are consistent with the behavior of the DM and OM digestibility coefficients, but, as in the growing phase, in the finishing phase the nutrient digestibility values reached a plateau (at the $60 \%$ concentrate level). NFC digestibility increased linearly $(p<0.05)$ with increasing concentrate levels in diets. This was expected, as the share of this component in the diet with $80 \%$ concentrate, as well as its consumption (g.animal ${ }^{-1}$.day ${ }^{-1}$ ) was $50 \%$ higher than in the diet with $20 \%$ concentrate (Tables 1 and 3). ADF digestibility coefficients declined ( $p$ $<0.05$ ) with increasing concentrate levels in the finishing phase diets. Thus, lignocellulose fraction degradation was impaired by increasing levels of concentrate. On the other hand, there was no effect of concentrate levels on NDF digestibility coefficients $(p>0.05)$, indicating that degradation of hemicellulose was not affected. There was also no effect of concentrate levels $(p>0.05)$ on ether 
extract digestibility coefficients in the finishing phase (Figure 2).

The nutrient digestibility and TDN values indicate that $60 \%$ concentrate in the diet of ewe lambs in the finishing phase is enough to promote the efficient use of nutrients and maximize energy intake (TDN). Higher levels (80\%) result in similar digestibility coefficients, suggesting that investing in higher levels of concentrate may be a waste of feed. Prediction equations were calculated to estimate levels of concentrate promoting maximum nutrient digestibility coefficient and TDN in the growing and finishing phases of the ewe lambs (Table 4).

Table 4. Regression equations the digestibility coefficients of nutrients in crossbred lambs fed with increasing levels of concentrate in the growing and finishing phases.

\begin{tabular}{|c|c|c|c|c|}
\hline Equations & Growing phase & $\mathrm{N}$ & SRMSE & $\mathrm{R}^{2}$ \\
\hline 1 & $\begin{array}{l}\text { Dry matter digestibility coefficient }(\%)=46.4^{* * *}( \pm 1.95)+0.699^{* * *}( \pm 0.090) \\
C-0.004^{* * *}( \pm 0.0009) C^{2}\end{array}$ & 66 & 2.91 & 83.4 \\
\hline 2 & $\begin{array}{l}\text { Organic matter digestibility coefficient }(\%)=48.7^{* * *}( \pm 1.91)+0.690^{* * *}( \pm 0.088) \\
\mathrm{C}-0.004^{* * *}( \pm 0.0009) \mathrm{C}^{2}\end{array}$ & 66 & 2.84 & 83.6 \\
\hline 3 & $\begin{array}{l}\text { Crude protein digestibility coefficient }(\%)=53.8^{* * *}( \pm 1.76)+0.900^{* * *}( \pm 0.082) \\
C-0.007^{* * * *}( \pm 0.0008) C^{2}\end{array}$ & 62 & 2.54 & 80.5 \\
\hline 4 & $\begin{array}{l}\text { Ether extract digestibility coefficient }(\%)=57.9^{* * *}( \pm 2.16)+0.607^{* * *}( \pm 1.00) \\
C-0.004^{* * *}( \pm 0.001) C^{2}\end{array}$ & 62 & 3.12 & 74.2 \\
\hline 5 & $\begin{array}{l}\text { Non-fibrous carbohydrate digestibility coefficient }(\%)=66.3^{* * *}( \pm 2.40)+ \\
0.865^{* * *}( \pm 0.112) \mathrm{C}-0.007^{* * *}( \pm 0.001) \mathrm{C}^{2}\end{array}$ & 62 & 3.47 & 66.4 \\
\hline 6 & $\begin{array}{l}\text { Neutral detergent fiber digestibility coefficient }(\%)=59.3^{* * *}( \pm 1.10)+ \\
0.135^{* * *}( \pm 0.020) \mathrm{C}\end{array}$ & 68 & 3.77 & 38.9 \\
\hline 7 & $\begin{array}{l}\text { Acid detergent fiber digestibility coefficient }(\%)=53.5^{* * *}( \pm 2.67)+ \\
0.398^{* *}( \pm 0.123) \mathrm{C}-0.004^{* * *}( \pm 0.001) \mathrm{C}^{2}\end{array}$ & 65 & 3.98 & 18.7 \\
\hline 8 & $\begin{array}{l}\text { Total digestible nutrientes }(\%)=51.5^{* * *}( \pm 1.72)+0.715^{* * *}( \pm 0.80) \mathrm{C}- \\
0.005^{* * *}( \pm 0.0008) \mathrm{C}^{2}\end{array}$ & 66 & 2.57 & 83.0 \\
\hline \multicolumn{5}{|c|}{ Finishing phase } \\
\hline 1 & $\begin{array}{l}\text { Dry matter digestibility coefficient }(\%)=53.1^{* * *}( \pm 2.01)+0.517^{* * *}( \pm 0.090) \\
C-0.003^{* *}( \pm 0.0009) C^{2}\end{array}$ & 43 & 2.32 & 83.1 \\
\hline 2 & $\begin{array}{l}\text { Organic matter digestibility coefficient }(\%)=54.6^{* * *}( \pm 2.07)+ \\
0.527^{* * *}( \pm 0.093) \mathrm{C}-0.003^{* *}( \pm 0.0009) \mathrm{C}^{2}\end{array}$ & 43 & 2.39 & 82.4 \\
\hline 3 & $\begin{array}{l}\text { Crude protein digestibility coefficient }(\%)=56.3^{* * *}( \pm 2.30)+0.796^{* * *}( \pm 0.103) \\
C-0.006^{* * *}( \pm 0.001) C^{2}\end{array}$ & 43 & 2.65 & 71.6 \\
\hline 4 & $\begin{array}{l}\text { Total digestible nutrientes }(\%)=56.9^{* * *}( \pm 1.92)+0.578^{* * *}( \pm 0.086) \mathrm{C}- \\
0.004^{* * *}( \pm 0.0008) \mathrm{C}^{2}\end{array}$ & 43 & 2.21 & 79.2 \\
\hline
\end{tabular}

${ }^{1} \mathrm{C}$ : concentrate level, $\% ; * * *(p<0.001) ; * *(p<0.01)$; N: number of observations; SRMSE: square root of the mean square error; $\mathrm{R}^{2}$ : coefficient of determination.

To obtain maximum digestibility values for $\mathrm{CP}$ (83\%) EE (81\%), NFC (93\%) and $\operatorname{ADF}(63 \%)$, concentrate must be included in the diet during the growing phase at $64.3,75.9,61.8$ and $49.8 \%$, respectively. The prediction equations for DM, OM, TDN and CP digestibility coefficients in the growing phase, with determination coefficients 83.4, 83.6 and 83.0, respectively, allow a precise estimation (low RMSE) of the proportion of concentrate in the diets. The maximum digestibility coefficients for DM (75.37\%) and OM (77.74\%) were obtained, from the equations, with $86.17 \%$ and 
$87.83 \%$ concentrate in the diet, respectively. The maximum TDN value $(77 \%)$ in the growing phase can be achieved by including $71.5 \%$ concentrate in the diet, and the highest $\mathrm{CP}$ digestibility coefficient in the finishing phase $(82.7 \%)$ can be achieved with $66.3 \%$ concentrate in the diet. The prediction equation for TDN has a coefficient of determination of $79.2 \%$, allowing precise (low RMSE) estimation of the TDN content in the diet from the level of concentrate added. According to this equation, adding $72.3 \%$ concentrate to the diet will result in $78 \%$ TDN, which is the diet digestibility plateau for ewe lambs in the finishing phase.

Although dry matter intake was similar between treatments (Table 2), average daily gain (ADG) and feed efficiency (FE) increased with concentrate levels $(\mathrm{p}<0.05)$ in the growing phase (Table 5).

Table 5. Least-squares mean, linear effect (LE) and quadratic effect (QE) of increasing levels of concentrate in the performance variables by crossbred lambs in the growing and finishing phases.

\begin{tabular}{|c|c|c|c|c|c|c|}
\hline \multirow{2}{*}{ Variables } & \multicolumn{4}{|c|}{ Concentrate levels } & \multicolumn{2}{|c|}{ P-Value } \\
\hline & $20 \%$ & $40 \%$ & $60 \%$ & $80 \%$ & CLE & CQE \\
\hline \multicolumn{7}{|c|}{ Growing phase } \\
\hline IBW & 23.63 & 25.31 & 26.07 & 27.45 & - & - \\
\hline FBW & 28.56 & 31.79 & 34.68 & 37.37 & - & - \\
\hline ADG & 135 & 168 & 218 & 246 & $<.0001$ & 0.832 \\
\hline FE & 0.110 & 0.150 & 0.180 & 0.200 & $<.0001$ & 0.249 \\
\hline \multicolumn{7}{|c|}{ Finishing phase } \\
\hline IBW & 28.56 & 31.79 & 34.68 & 37.37 & - & - \\
\hline FBW & 36.23 & 39.77 & 43.63 & 47.85 & - & - \\
\hline $\mathrm{ADG}$ & 162 & 159 & 162 & 171 & 0.791 & 0.678 \\
\hline FE & 0.111 & 0.119 & 0.125 & 0.141 & 0.105 & 0.812 \\
\hline
\end{tabular}

IBW: initial body weight, kg; FBW: final body weight, kg; ADG: average daily gain, g/day; FE: feed efficiency, average daily gain $\left(\right.$ g.day $\left.^{-1}\right) /$ dry matter intake $\left(\right.$ g.day $\left.{ }^{-1}\right)$.

These results were associated with increasing nutrient digestibility coefficients and TDN (Figure 1) that contributed to increase the intake and absorption of nutrients in the gastrointestinal tract and availability of digestible energy to the animal. Multiplying TDN by 4.4 yields the digestible energy content of the diet (DE), which, when multiplied by 0.82 , yields the metabolizable energy (ME) available to meet the animal growth and maintenance requirements (NRC, 2007). Thus, theoretically, the higher the concentrate level and the TDN value, the higher the DE and ME content of the diet. However, TDN values from the digestibility trials in this study displayed a quadratic behavior (Figure 1), whereas, as discussed above, the results of weight gain and feed efficiency grew linearly $(p<0.05)$. Thus, the maximum TDN value obtained during the growing phase $(77 \%)$ was achieved with $60 \%$ concentrate, but the animals that received $80 \%$ concentrate had on average a $12 \%$ higher weight gain than those fed $60 \%$ concentrate.

Based on the quadratic effects on the digestibility coefficients, ADG and FE should have displayed a behavior similar to TDN. However, other reasons, discussed below, may justify the performance observed. Ewe lambs fed $80 \%$ concentrate in the growing phase probably used digestible energy (DE) in the diet more efficiently than those subjected to other conditions, especially those fed $60 \%$ concentrate (TDN plateau), due to the reduction of caloric increment promoted by diets with high concentrate ratios. Thus, diets with $80 \%$ concentrate 
possibly provided more ME for maintenance and tissue deposition, resulting in increased weight gain and feeding efficiency, even with the maximum TDN being similar to that achieved with $60 \%$ concentrate (Figure 1). Thus, to explore the potential for efficient use of diets by the animals and, at the same time, reduce investment in concentrate, the inclusion of $60 \%$ concentrate in the diet is enough to ensure good results of diet digestibility in growing phase ewe lamb production systems. However, if the producer aims to accelerate weight gain rates, in order to reach the finishing or reproduction phase faster, $80 \%$ concentrate yields better results.

Concentrate levels had no effect $(p>0.05)$ on $\mathrm{ADG}$ and FE in ewe lambs in the finishing phase. Animals in this phase had body weight above $33 \mathrm{~kg}$, close to the adult size for the species (MALHADO et al., 2008). Although, regardless of concentrate levels, all animals might be considered adults, the final body weight variation resulted from increased tissue deposition during the growing phase, resulting in differences in body composition among these animals.

During the finishing phase, body weight increased by about $8 \mathrm{~kg}$, as a result of similar TDN intake (Table 3), but energy partition to meet maintenance and gain requirements were different, as the animals supplemented with $80 \%$ concentrate deposited a larger proportion of fat (CACERE et al., 2014). Smaller body size animals in this study demanded less metabolizable energy requirements for maintenance, but higher estimated metabolizable energy requirements for weight gain (MORAIS et al., 2016). In the growing phase requirements for weight gain are higher because in lighter animals muscle tissue synthesis predominates, and this is considered a less energy efficient process due to increased deposition of water (OWENS et al., 1993).

On the other hand, due to their larger size, the ewe lambs treated with $80 \%$ concentrate in the finishing phase had higher metabolizable energy requirements for maintenance, reducing the availability of net energy for gain (MORAIS et al., 2016). According to MORAIS et al. (2016), the largest ewe lambs, supplemented with $80 \%$ concentrate, used TDN similarly to the ewe lambs subjected to other treatments, but as they continued depositing higher proportions of fat, a more efficient biochemical process than muscle tissue synthesis, those animals achieved more weight gain for the same net energy. According to Owens et al. (1993), the greater the proportion of fat in the growth, the higher the weight gain. For each gram of protein deposited $5.6 \mathrm{kcal}$ are retained, compared to 9.4 kcal retained for each gram of lipid deposited. Thus, as the animal approaches mature size, even if it is fed diets with similar energy content in the growing and finishing phases, it uses more of every kcal provided by the diet for fat deposition.

Besides the increase of body fat deposition, increasing levels of concentrate resulted in a significant increase in the thickness of the carcass fat cover, as Cacere et al. (2014) showed when evaluating the carcass characteristics of animals in this work. According to those authors, adding 80\% concentrate to the diet caused excessive thickness of subcutaneous fat on the carcass, compared to ewe lambs fed with $20 \%$ concentrate $(7.41 \mathrm{~mm}$ vs. $2.24 \mathrm{~mm})$. Together, these results indicate that supplementation with $20 \%$ concentrate in the finishing phase is sufficient to provide satisfactory performance and ensure the minimal carcass finish required by the meatpacking industry.

\section{Conclusion}

The use of $60 \%$ concentrate in the diet of feedlot crossbred ewe lambs during the growing phase, and $20 \%$ concentrate in the finishing phase are recommended to maximize nutrient utilization, performance and to prevent feed waste. 


\section{Acknowledgements}

We thank the Fundação de Apoio ao Desenvolvimento do Ensino, Ciência e Tecnologia from the state of Mato Grosso do Sul, Brazil, for financial support.

\section{References}

BOLZAN, I. T.; SANCHEZ, L. M. B.; CARVALHO, P. A.; VELHO, J. P.; LIMA, L. D.; CADORIN, R. L. Consumo e digestibilidade em ovinos alimentados com dietas contendo grão de milho moído, inteiro ou tratado com ureia, com três níveis de concentrado. Ciência Rural, Santa Maria, v. 37, n. 1, p. 229-234, 2007.

CACERE, R. A. S.; MORAIS, M. G.; ALVES, F. V.; FEIJÓ, G. L. D.; ÍTAVO, C. C. B. F.; OLIVEIRA, L. B.; PIRES, C. C. Quantitative and qualitative carcass characteristics of feedlot ewes subjected to increasing levels of concentrate in the diet. Arquivo Brasileiro de Medicina Veterinária e Zootecnia, Belo Horizonte, v. 66, n. 5, p. 1601-1610, 2014.

CARASSAI, I. J.; NABINGER, C.; CARVALHO, P. C. F.; SANTOS, D. T.; FREITAS, F. K.; DEVINCENZI, T.; CARDOSO, R. R. Recria de cordeiras em pastagem nativa melhorada submetida à fertilização nitrogenada. 2. Produção animal. Revista Brasileira de Zootecnia, Viçosa, MG, v. 37, n. 10, p. 1815-1822, 2008.

CARVALHO, S.; DIAS, F. D.; PIRES, C. C.; WOMMER, T. P.; VENTURINI, R. S.; FRASSON, M. F.; PILECCO, V. M.; MORO, A. B.; BRUTTI, D. D. Consumo e desempenho produtivo de cordeiros das raças Texel e Ideal terminados em confinamento com dietas contendo diferentes teores de casca de soja. Semina Ciências Agrarias, Londrina, v. 36, n. 3, p. 2131-2140, 2015.

CUNHA, M. G. G.; CARVALHO, F. F. R.; GONZAGA NETO, S. G.; CEZAR, M. F. Características quantitativas de carcaça de ovinos Santa Inês confinados alimentados com rações contendo diferentes níveis de caroço de algodão integral. Revista Brasileira de Zootecnia, Viçosa, MG, v. 37, n. 6, p. 1112-1120, 2008.

FRESCURA, R. B. M.; PIRES, C. C.; ROCHA, M. G. da; SILVA, J. H. S. da; MULLER, L. Sistemas de alimentação na produção de cordeiros para abate aos 28 kg. Revista Brasileira de Zootecnia, Viçosa, MG, v. 34, n. 4, p. 1267-1277, 2005.

GERON, L. J. V.; MEXIA, A. A.; CRISTO, R. L.; GARCIA, J.; CABRAL, L. S.; TRAUTMANN, R. J.; MARTINS, O. S.; ZEOULA, L. M. Consumo, digestibilidade dos nutrientes e características ruminais de cordeiros alimentados com níveis crescentes de concentrado em ambiente tropical no Vale do Alto Guaporé - MT. Semina: Ciências Agrárias, Londrina, v. 34, n. 5, p. 2497-2510, 2013.

HALL, M. B. Calculation of non-structural carbohydrate content of feeds that contain non-protein nitrogen. Gainesville: University of Florida, 2000. 77 p. (Bulletin, 339).

KOZLOSKI, G. V.; TREVISAN, L. M.; HÃTER, L. M.; GALVANI, D. B.; PIRES, C. C. Níveis de fibra em detergente neutro na dieta de cordeiros: consumo, digestibilidade e fermentação ruminal. Arquivo Brasileiro de Medicina Veterinária e Zootecnia, Belo Horizonte, v. 58, n. 5, p. 893-900, 2006.

MALHADO, C. H. M.; CARNEIRO, P. L. S.; SANTOS, P. F.; AZEVEDO, D. M. M.; SOUZA, J. C.; AFFONSO, R. M. Curva de crescimento em ovinos mestiços Santa Inês x Texel criados no Sudoeste do Estado da Bahia. Revista Brasileira de Saúde e Produção Animal, Salvador, v. 9, n. 2, p. 210-218, 2008.

MORAIS, M. G.; FERNANDES, H. J.; OLIVEIRA, L. B.; RIBEIRO, C. B.; SOUZA, A. R. D. L.; FRANCO, G. L.; ÍTAVO, C. C. B. F.; ANDRADE, A. G. F.; ÍTAVO, L. C. V.; MELO, G. K. A.; WALKER, C. C. Exigências de energia de borregas mestiças alimentadas com níveis crescentes de concentrado na dieta. Arquivo Brasileiro de Medicina Veterinária e Zootecnia, Belo Horizonte, v. 68, n. 4, p. 1023-1032, 2016.

MORENO, G. M. B.; SOBRINHO, A. G. S.; LEÃO, A. G.; LOUREIRO, C. M. B.; PEREZ, H. L.; ROSSI, R. C. Desempenho, digestibilidade e balanço de nitrogênio em cordeiros alimentados com silagem de milho ou cana-deaçúcar e dois níveis de concentrado. Revista Brasileira de Zootecnia, Viçosa, MG, v. 39, n. 4, p. 853-860, 2010.

NATIONAL RESEARCH COUNCIL - NRC. Nutrients requirements of small ruminants. Washington: National Academy Press, 2007. 362 p.

OWENS, F. N.; DUBESKI, P.; HANSON, C. F. Factors that alter the growth and development of ruminants. Journal of Animal Science, Savoy, v. 71, n. 11, p. 31383150, 1993.

OWENS, M. F. N.; ZINN, R. A.; KIM, Y. K. Limits to starch digestion in the ruminant small intestine. Journal of Animal Science, Savoy, v. 63, n. 5, p. 1634-1648, 1986.

SILVA, A. E. M. da; LIRA, A. T.; FERREIRA, M. A.; BARROS, L. J. A.; MELO, T. T. B.; SIQUEIRA, T. D. Q.; SOARES, L. F. P.; COSTA, C. T. F. Bagaço de cana-de-açúcar como volumoso exclusivo em dietas para ovinos. Revista Brasileira de Saúde e Produção Animal, Salvador, v. 16, n. 1, p. 118-129, 2015. 
SILVA, D. J.; QUEIROZ, A. C. de. Análise de alimentos: métodos químicos e biológicos. 3. ed. Viçosa, MG: Ed. UFV, 2002. $235 \mathrm{p}$.

STATISTICAL ANALYSIS SYSTEM INSTITUTE SAS Institute. Statistical Analysis System. SAS versão 9.2. Cary: SAS Inst. Inc., 2009.
STEEL, R.; TORRIE, J. H.; DICKEY, D. A. Principles and procedures of statistics. a biometrical approach. New York: McGraw-Hill Co., 1997. 666 p. 